\title{
PENGARUH PELATIHAN MOTIVASI BERBASIS OTAK TERHADAP KEKUATAN LIMBIK , ABILITAS, KREATIFITAS DAN KEMAUAN SISWA
}

\author{
Abdul Razak* ${ }^{*}$ Rusdina \\ Program Pascasarjana Universitas Negeri Padang (UNP)
}

\begin{abstract}
This study aims to prove the effect of motivational training based on the strength of the brain, limbic, ability, creativity and willingness of third grade students of SMPN 9 Sijunjung. This research is the application of neuroscience in education that has been studied for five years. Metodeyang Kinesiology is the method which is the study of the nerves in the arm that had been developed by experts for the detection of various diseases and are able to explain scientifically the cause of it with electromagnetic waves tubuh.Selanjutnya mechanisms, methods perrmainan motivation (motivation game) can measure abiliotas, creativity and willingness of students. The results showed a marked influence, dimana85.30\% limbic conditions SMPN 9 at a weak level. Meanwhile, the rest in a rather weak condition of $11.77 \%$ and limbic strong with a percentage of $0.03 \%$ .In time before pelatihan. Setelah training, limbic level kuatmenjadi 0:06\%. Limbic weak condition was reduced to $42.42 \%$.Next, before the training, the value of creativity, and willingness abilitas each is 12-109, 12-93 and 16-82. After the training level of creativity, and the willingness of students abilitas increases with each range of 38-137, 22-96 and 29-150. Evidently, motivational training based mempengaruhikekuatan limbic brain, abilitas, creativity and willingness of third grade students of SMPN 9 Sijunjung, West Sumatra
\end{abstract}

\section{Keywords: Kinesiology, abiltty, creativity, willingness, motivation-based brain training}

\begin{abstract}
ABSTRAK
Penelitian ini untuk bertujuan membuktikan pengaruh pelatihan motivasi berbasis otak terhadap kekuatan limbik, abilitas, kreatifitas dan kemauan siswa kelas III SMPN 9 Kabupaten Sijunjung. Penelitian ini merupakan aplikasi neurosains dalam bidang pendidikan yang telah diteliti selama lima tahun. Metodeyang digunakan adalah metode Kinesiologi yang merupakan ilmu yang mempelajari tentang saraf-saraf pada lengan yang telah dikembangkan oleh ahlinya untuk deteksi berbagai penyakit dan mampu menjelaskan secara ilmiah penyebab hal tersebut dengan mekanisme gelombang elektromagnetis tubuh.Selanjutnya, metode perrmainan motivasi (game motivation) dapat mengukur abiliotas, kreativitas dan kemauan siswa. Hasil penelitian
\end{abstract}


menunjukkan pengaruh yang nyata, dimana85.30 \% kondisi limbik siswa SMPN 9 pada taraf yang lemah. Sementara, sisanya dalam kondisi agak lemah $11.77 \%$ dan limbik yang kuat dengan prosentase 0.03\%.pada saat sebelum pelatihan.Setelah pelatihan, limbik level kuatmenjadi $0.06 \%$. Kondisi limbik yang lemah berkurang menjadi $42.42 \%$. Selanjutnya, sebelum pelatihan, nilai kreatifitas, abilitas dan kemauan masing-masing adalah 12-109, 12-93 dan 16-82. Setelah pelatihan tingkat kreativitas, abilitas dan kemauan siswa meningkat dengan rentang masing-masing 38-137, 22-96 dan 29-150. Terbukti, pelatihan motivasi berbasis otak mempengaruhikekuatan limbik, abilitas, kreatifitas dan kemauan siswa kelas III SMPN 9 Kabupaten Sijunjung, Sumatera Barat

Katakunci : Kinesiologi, abilitas, kreativitas, kemauan, pelatihan motivasi berbasis otak

\section{PENDAHULUAN}

Motivasi sumber energi pendorong untuk melakukan aktivitas harian yang berulang. Hal ini terjadi dan dialami oleh seorang guru ketika mengajar. Motivasi seperti laksana air laut, mengalami pasang surut.Ada saatnya naik dan ada saatnya turun.Oleh karena itu, revitalisasi yang bermakna penyegaran dan pembaharuan motivasi perlu dilakukan.Motivasi sangat berpengaruh terhadap kinerja dan kualitas pembelajaran.Kinerja dan kualitas pembelajaran signifikan mempengaruhi hasil belajar harian maupun berkala seperti ujian Nasional yang dilaksanakan setiap tahun.

Hal tersebut di atas didukung oleh pengalaman peneliti dalam melaksanakan kegiatan pelatihan motivasi sejak tahun 2006 di beberapa sekolah menengah negeri dan sekolah menengah swasta di Kotamadya Padang, Kabupaten Sijunjung dan serta Madrasah Aliyah Negeri 2 di Kotamadya Payakumbuh. Sejak bulan Februari 2006 sampai Januari 2009 telah melaksanakan 12 kali pelatihan peningkatan motivasi guru dan 6 kali pelatihan motivasi untuk siswa kelas III SMA, dalam usaha peningkatan hasil belajar untuk menghadapi Ujian Nasional. Pelatihan tersebut mampu meningkatkan hasil UN di MAN 2 Payakumbuh secara signifikan. Di Kotamadya Padang, guru-guru IPA-IPS dan siswa Kelas III IPA dan IPS dari 2 SMA negeri yakni SMAN 7 dan SMAN 9 serta SMAS PGRI 1 Padang yang diberikan pelatihan peningkatan motivasi dengan pendekatan pencerahan dan pembelajaran berbasis otak berhasil meningkatkan hasil UN tahun 2008 secara signifikan. Di SMAN 7 hasil UN 2008 memperoleh kenaikan 
menjadi 99.99\%. Di SMAN 9 Padang, hasil UN 2008 meningkat menjadi 100\% dan meraih peringkat nilai UN terbaik nomor dua (2) se-SMA di Kotamadya Padang. Di waktu yang sama SMAS PGRI 1 Padang hasil UN tahun 2008 meningkat dari $75 \%$ menjadi $96 \%$. Hasil tersebut menunjukkan bahwa revitalisasi motivasi bagi guru dan siswa melalui pencerahan dan pembelajaran berbasis otak yang menyenangkan mampu meningkatkan hasil belajar dan hasil UN secara nyata.

Untuk mengetahui sejauh mana pengaruh pendekatan pencerahan dan motivasi berbasis otak terhadap motivasi siswa dilakukan pelatihan tersebut sebagai suatu cara. Hal ini diharapkan mampu meningkatkan hasil belajar siswa SMP.

Selanjutnya, penelitian ini merupakan bentuk sinergi dua bidang ilmu yakni Ilmu Biologi dalam hal ini neurosains (IPA) dengan ilmu pendidikan (IPS).Sinergi keduanya diharapkan memberikan kontribusi bagi peningkatan kualitas pembelajaran dan hasil belajar sekolah sasaran.Selama ini, penelitian motivasi yang dikombinasikan dengan neurosains masih minim dilakukan. Padahal, saat ini, sudah terbukti berdasarkan pengalaman dan hasil penelitian para peneliti perintis bidang neurosains, pemahaman tentang cara kerja otak cukup efektif meningkatkan kualitas pembelajaran.

Keutamaan atau keunggulan motivasi berbasis otak adalah siswa menjadi senang belajar.Rasa senang muncul karena pembelajaran berbasis otak mampu mengaktivasi otak saat mulai belajar laksana saklar lampu pada posisi "on" artinya siap memori otak siap menerima. Proses belajarnya sesuai dengan kesukaan otak (emosi/ sistem limbik) sehingga menimbulkan respon senang belajar dan senang dengan guru yang mengajarkan. Hal ini membuat proses pembelajaran alamiah terjadi seperti air mengalir.

Keutamaan atau keunggulan pencerahan dan pembelajaran berbasis otak adalah siswa menjadi senang belajar.Rasa senang muncul karena pembelajaran berbasis otak mampu mengaktivasi otak saat mulai belajar laksana saklar lampu pada posisi "on" artinya siap memori otak siap menerima. Proses belajarnya sesuai dengan kesukaan otak yakni mendengar musik membuat gelombang otak pada taraf alfa sehingga menimbulkan respon senang belajar dan senang dengan 
guru yang mengajarkan. Hal ini membuat proses pembelajaran alamiah terjadi seperti air mengalir. Sisi lain pencerahan berimbas bagi guru pada tataran filosofis belajar dan dampaknya bagi eksistensi bangsa di masa depan. Dampaknya, guru disadarkan betapa besar dan berartinya seorang guru bagi suatu bangsa. Seorang guru mempengaruhi kesuksesan ribuan orang anak bangsa 10-30 tahun ke depan. Kesadaran mendalam akan fungsi dan pengaruh guru inilah yang memicu motivasi guru untuk memperbaiki dan meningkatkan kualitas pembelajaran.

Motivasi mempengaruhi sistem limbik otak manusia.Otak mamalia (sistem limbic) memiliki potensi-potensi yang berkaitan dengan fungsi-fungsi emosional dan kognitif.Artinya, pada bagian ini tersimpan perasaan dan memori kita. Selain itu, bagian ini juga bertanggung jawab terhadap bioritmik tubuh kita, seperti pola tidur, tekanan darah, denyut jantung, metabolisme, imunitas, gairah sexual, dan lainsebagainya Karena emosi dapat mempengaruhi tubuh secara keseluruhan, maka penting sekali untuk menjaga emosi kita untuk selalu positif.

Selanjutnya, tehnik Kinesiologi terapan adalah sebuahn sistem uji fisik, mental dan kondisi kimiawi dari kesehatan tubuh dengan menggunakan otot tangan secara manual dan standar lainnya sebagai sebuah metode diagnosa. Kinesiologi terapan ini adalah metode diagnosa concentius yang mampu memberikan umpan balik tentang fungsi-fungsi tubuh yang lemah Applied Kinesiology (AK-test) melibatkan sejumlah perlakuan yang dapat di lakukan dengan caramyofacial therapies, cranial techniques, meridian and acupuncture skills, clinical nutrition, dietary management, counseling skills, environmental irritants and reflex procedures..AK-test ini mampu mengevaluasi kondisi fisik, kimia dan ketidakseimbangan mental dan dapat memberikan terapi bagi ketidakseimbangan tersebut. AK test dapat didukung oleh chiropatic treatment seperti iridologi, obat-obatan, osteopathy dan sebagainya. Emosi positif perlu dijaga. Karena itulah pelatihan motivasi berbasis otak merupakan cara cepat menjaga emosi siswa. Siswa SMP emosinya sering labil.Hal ini secara langsung mempengaruhi kemampuan, kecerdasan, kreatifitas dan kemauan dalam belajar.Adapun tujuan penelitian ini untuk membuktikan pengaruh pelatihan motivasi berbasis otak terhadap kekuatan limbik, abilitas, kreatifitas dan kemauan siswa kelas III SMPN 9 Kabupaten Sijunjung 


\section{METODE PENELITIAN}

\section{A. Populasi dan Sampel}

Penelitian ini dilaksanakan pada bulan 1 November-10 Desember 2011 di SMPN 9Kabupaten Sijunjung. Penelitian ini diikuti oleh 68 orang siswa kelas III SMP yang merupakan populasi dan sampelsiswa yang diambil sebagai subjek penelitian adalah 34 orang.

\section{B. Alat dan Bahan}

Alat penelitian ini adalah kamera digita..LCD, Laptop dan Sound System.Bahan berupa battery Alkaline AA 3 set dan buku berisi petunjukkertas HVS, bahan peraga atau simulasi

\section{Cara kerja}

Kegiatan di awali dengan pengamatan level kecerdasan dengan Kinesiologi dan Tes kreativitas, abilitas dan Willness (kemauan) pada saat sebelum dan sesudah pelatihan. Hal ini dilakukan sebelum dan sesudah pelatihan motivasi belajar berbasis otak. Hal tersebut dilakukan untuk mengetahui respon siswa terhadap pelatihan yang diberikan. Pelatihan motivasi belajar berbasis otak untuk siswa sebagai solusi berisi materi : 1) Motivasi diri, 2) Aplikasi

Motivasi dalam Pembelajaran, 3) Kesenangan Otak, 4) Kiat-kiat Sukses Ujian. Pelatihan dilaksanakan mulai jam 9.00-16.00 WIB. Kegiatan pelatihan dilaksanakan dengan metode ceramah, Tanya jawab, menggunakan infokus dan powerpoint, pemutaran video dan disampaikan dengan santai, penuh humor serta pelatih mampu menyenangkan siswa.

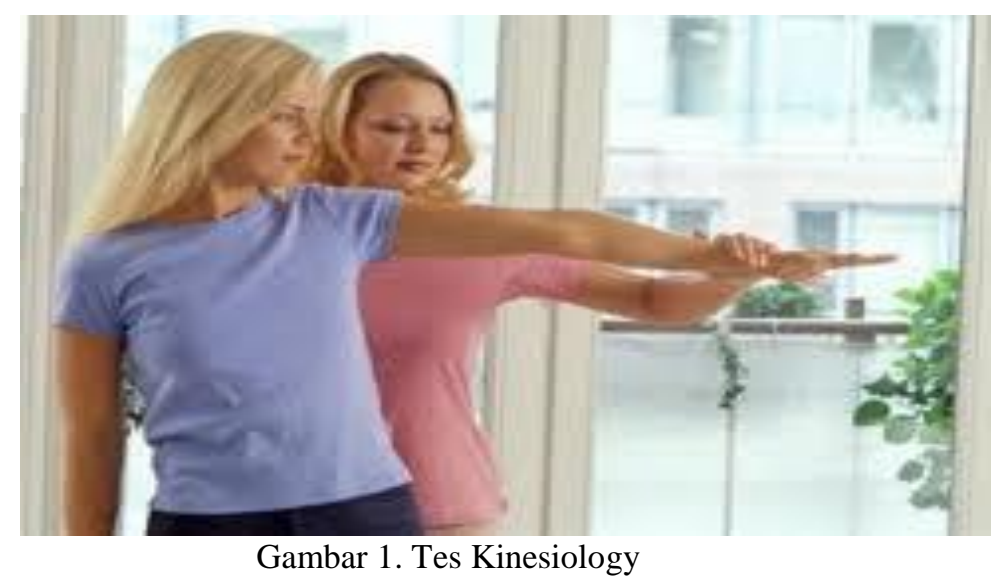

(http://www.google.co.id/imglanding/Kinesiologymethod 2011 


\section{HASIL DAN PEMBAHASAN}

\section{A. Analisis Tingkat Kecerdasan Siswa kelas III SMPN Kabupaten Sijunjung.}

Pada penelitian ini, sebelum dilakukan pelatihan motivasi, peneliti melakukan perkenalan kepada Kepala Sekolah dan Guru SMPN 9 Kabupaten Sijunjung. Pelaksanaan penelitian ini difasilitasi oleh Kepala Bidang Mutu dan Kepala Bidang Pendidikan Sekolah Dasar dan Menengah Dinas Pendidikan Sijunjung. Kabupaten Selanjutnya, dengan bantuan Kepala sekolah dan guru diadakan pertemuan dengan siswa dan orang tuanya. Setelah orang tua setuju, sekolah mempersiapkan hal-hal yang terkait dengan penelitian ini. Tahap I penelitian ini adalah analisis Limbic untuk mengetahui tingkat kecerdasan siswa. Limbic merupakan bagian otak. Pada limbic terletak kecerdasaran dan emosi. Hal ini dapat dilihat pada Gambar 2. Sistem Limbik atau otak tengah, yang posisinya sedikit lebih ke depan dan terdiri atas Talamus dan Ganglia Basal atau otak tengah. Sistem Limbik penting bagi pembelajaran dan ingatan jangka pendek tetapi juga menjaga homeostatis di dalam tubuh (tekanan darah, suhu tubuh dan kadar gula darah). Terlibat dalam emosi ketahanan hidup dari hasrat seksual atau perlindungan diri.Menurut ilmuwan Robert Ornstein "suatu cara untuk mengingat fungsi sistem limbik adalah empat $\mathrm{F}$, yang penting untuk kelangsungan hidup :Feeding(memberi makan), Fighting (berkelahi), Fleeing (melarikan diri), dan reproduksi sosial. Limbic atau otak tengah ini disebut juga otak mammalia (Rose dan Nicholl, 2002).

Kekuatan dan kelemahan sistem Limbic dapat diperiksa secara Kinesiologi. Kinesiologi adalah cabang ilmu saraf yang khusus mempelajari saraf pada otot lengan dan kaki. Kinesiologi ditemukan oleh Dr. G.Good Heart, DC dan selanjutnya, Positron emission tomography (PET) dan pencitraan resonansi magnetik fungsional (fMRI) telah menunjukkan bahwa sistem limbik adalah salah satu daerah otak yang paling aktif selama proses bermimpi. Sistem limbik mungkin menjalin emosi primal sadar dengan pikiran kita sadar kognitif dan persepsi dan dengan demikian ikatan bersama-sama emosi dan memori selama gerakan mata cepat (REM) tidur untuk membentuk isi mimpi. Suprachiasmatic nucleus dari hipotalamus adalah generator ritme sirkadian mengendalikan siklus tidur-bangun. ventrolateral nukleus preoptic (VLPO) dari hipotalamus 
mengirimkan proyeksi ke inti tuberomamillary histaminergic (TMN), dorsal serotonergik dan median raphe nucleus dan noradenergic coeruleus locus. Hal ini juga mengirimkan akson yang mengakhiri dalam otak depan basal kolinergik, inti pedunculopontinethalamic (PPT) dan dorsal lateral yang inti thalamic (LDT). VLPO proyeksi ke daerah ini hambat di alam karena mereka $\gamma$-aminobutyric acidergik (GABAergic) dan galaninergic. The VLPO melalui penghambatan mekanisme gairah besar, berfungsi sebagai 'saklar tidur', mempromosikan tidur. Hubungan timbal balik dengan daerah gairah besar membantu itu berfungsi sebagai salah satu setengah dari 'flip-flop' sirkuit, penembakan stabil (flip-flop) yang mencegah negara-negara menengah tidur dan terjaga. The VLPO oleh disinhibisi nya dari PPT-LDT juga mempromosikan tidur REM. Daerah hipotalamus lateral (LHA) mengandung neuron orexinergic yang mempromosikan terjaga. Neuron orexinergic menghambat tidur-mempromosikan neuron tidurmempromosikan VLPO dan REM di PPT-LDT. Neuron orexinergic juga meningkatkan penembakan lokus coeruleus, dorsal raphe dan TMN dan dengan cara, bertindak sebagai jari menekan 'flip-flop' circuit switch ke posisi terjaga (Indian Journal Psychiatry, 2007).

Diteliti oleh para ahli Dr.Alan Beardal yang menerapkannya untuk diagnosa 300 jenis penyakit dengan menekan otot lengan dan kaki untuk mengetahui level energi sistem saraf kuat atau lemah. Tehnik ini dikembangkan dalam Applied Kinesiology (Kinesiologi Terapan)(Rivai, 2006). Pada penelitian minggu pertama, jumlah siswa kelas III SMPN 9 Kabupaten Sijunjung berjumlah 34 orang. Saat penelitian dilaksanakan hadir 34 orang. Adapun hasil pemeriksaan kekuatan dan kelemahan limbic pada siswa siswa kelas kelas III SMPN 9 Kabupaten Sijunjung terdapat pada Tabel 1. 
Tabel 1. Tingkat Kekuatan/Kelemahan LimbicSiswa SebelumPelatihan Motivasi

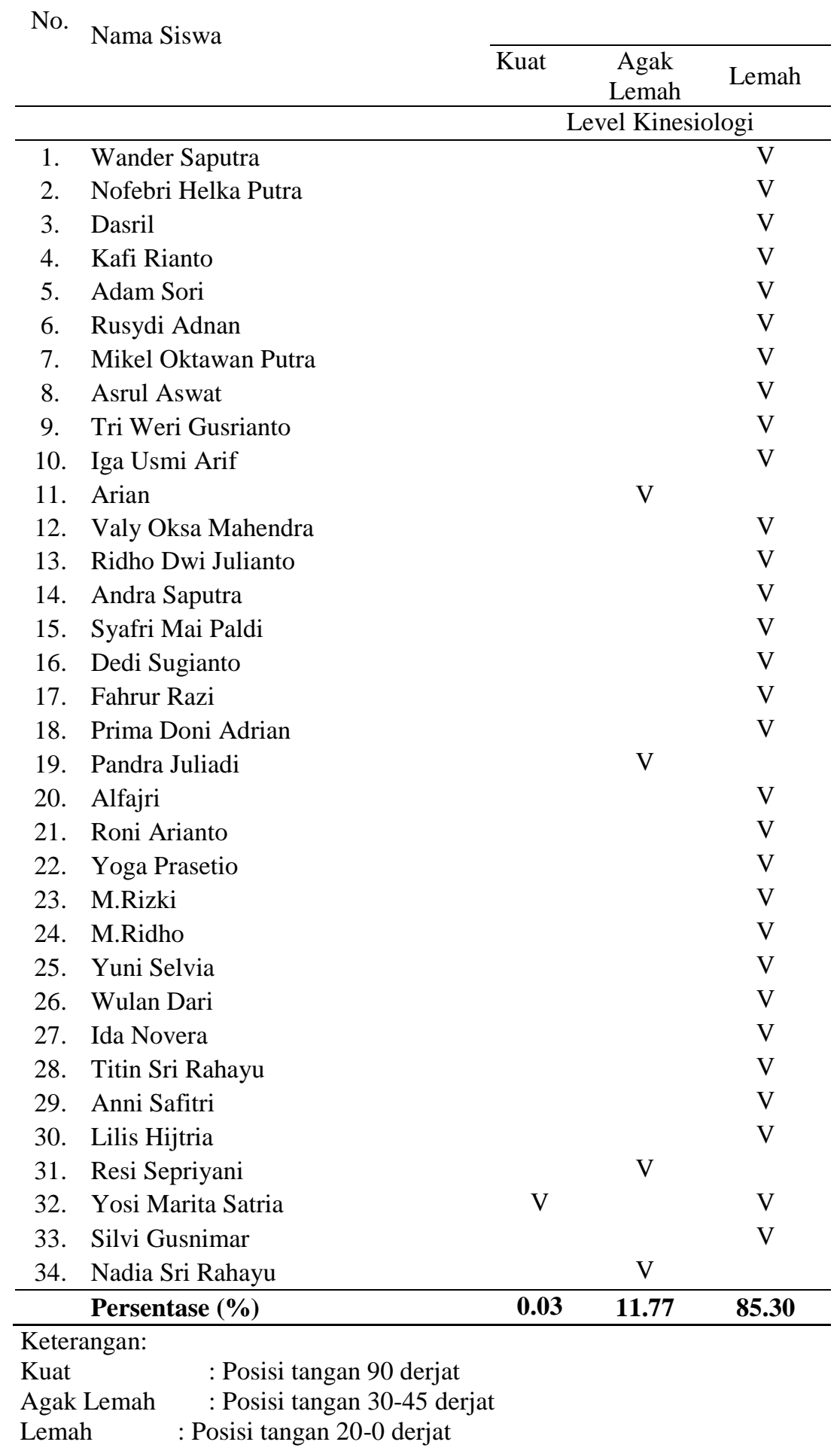

Data pada Tabel 1-2 menunjukkan bahwa level kelemahan/kekuatan limbic sebelum dan setelah pelatihan menunjukkan hasil yang nyata berubah. Tabel 1 menunjukkan 85.30\% kondisi limbic siswa SMPN 9 pada taraf yang 
lemah. Sementara, sisanya dalam kondisi agak lemah $11.77 \%$ dan limbik yang kuat dengan prosentase $0.03 \%$. Pada Tabel 2, kelemahan limbik berubah setelah pelatihan menjadi kuat dengan prosentase $0.06 \%$. Kondisi limbik yang lemah berkurang menjadi $42.42 \%$.

Tabel 2. Tingkat Kekuatan/Kelemahan LimbikSiswa SetelahPelatihan Motivasi

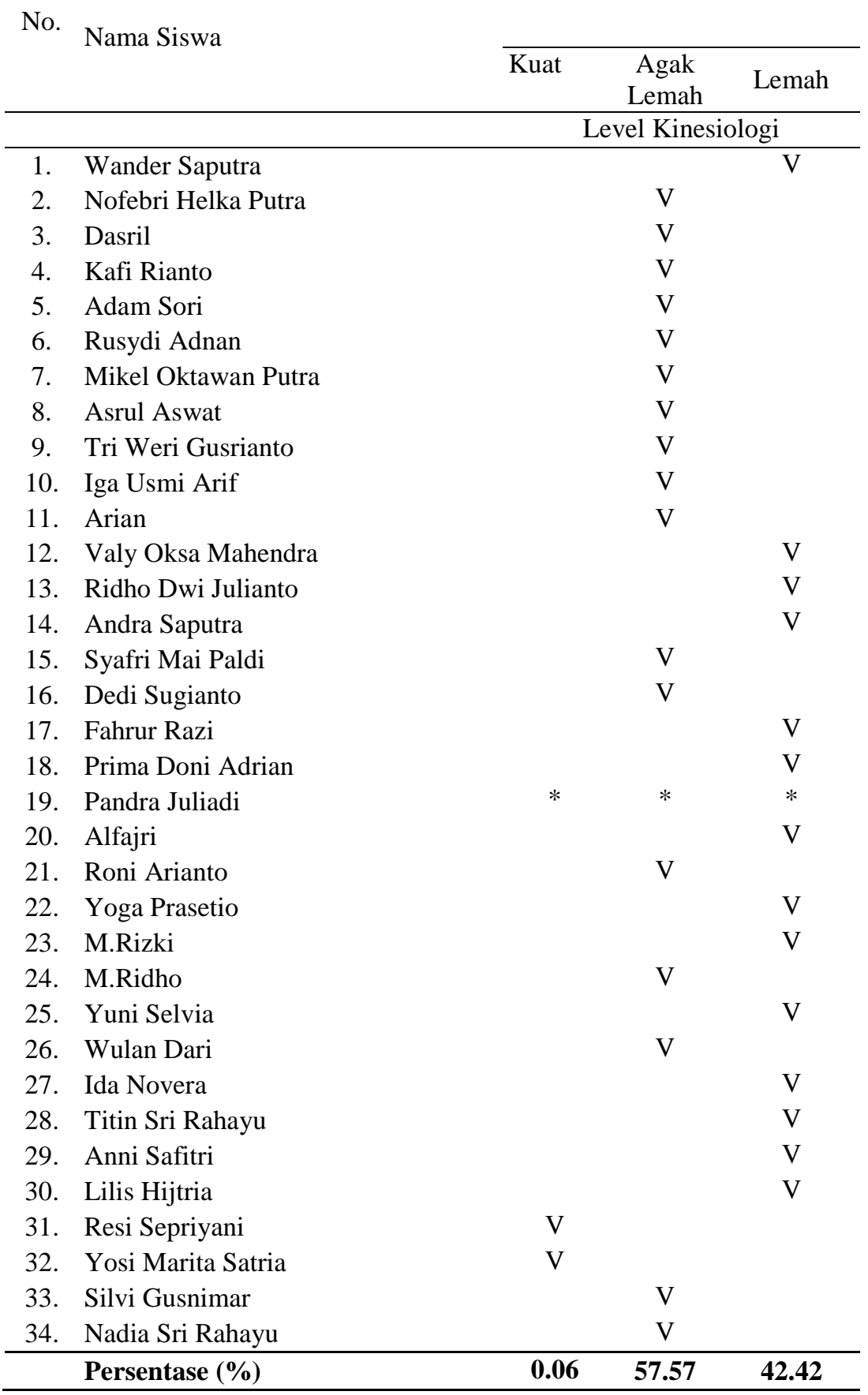

Keterangan

Kuat : Posisi tangan 90 derjat * Siswa pulang saat pelatihan berlangsung.

Agak Lemah : Posisi tangan 30-45 derjat

Lemah : Posisi tangan 20-0 derjat 
Kondisi atau tingkat limbic yang agak lemah meningkat menjadi 57.57\%. Sulitnya meningkatkan kondisi limbic siswa kelas III SMPN Sijunjung ini akibat siswa tidak memiliki energi belajar yang cukup di pagi hari. Hal ini merupakan akibat dari kebiasaan siswa yang tidak pernah sarapan pagi. Para siswa di SMPN 9 ini makan pada siang hari setelah mereka pulang ke rumah. Kondisi ini sudah sering disampaikan kepada para orangtua siswa namun orangtua siswa tidak mempu melakukannya karena faktor ekonomi yang lemah, kebiasaan tidak makan pagi dan rendahnya tingkat pendidikan orangtua yang umumnya adalah buruh tani dengan tingkat pendidikan paling tinggi tamat SMP dan kebanyakan tamat SD atau tidak tamat SD. Hal ini disampaikan dengan komunikasi pribadi oleh Kepala Sekolah, guru Matematika dan Wakil Kepala Sekolah Bidang Kurikulum SMPN 9

\section{B. Tingkat Kreativitas, Abilitas dan Kemauan (Willingness)}

Tabel 3. Tingkat Kreativitas (K), Abilitas (A) dan Willness (W) (Kemauan) Sebelum Pelatihan

\begin{tabular}{|c|c|c|c|c|}
\hline No. & Jumlah Siswa & Kreatifitas & Abilitas & $\begin{array}{l}\text { Willingness } \\
\text { (Kemauan) }\end{array}$ \\
\hline & 34 & $12-109$ & $12-93$ & $16-82$ \\
\hline
\end{tabular}

Demikian juga halnya pada Tabel 3-4 yang menunjukkan peningkatan kreativitas, abilitas dan willness (kemauan) setelah pelatihan. Hal ini membuktikan bahwa pelatihan mampu meningkatkan kekuatan limbik dan juga meningkatkan level kreativitas, abilitas dan kemauan siswa secara nyata.

Tabel 3 di atas menunjukkan bahwa tingkat kreatifitas, abilitas dan kemauan para siswa SMPN 9 kabupaten Sijunjung bervariasi dari rendah sampai tinggi. rentang nilai kreatifitas, abilitas dan kemauan masing-masing adalah 12109, 12-93 dan 16-82. Soenarno (2006) yang menyatakan rentang nilai kreatifitas, abilitas dan kemauan yang dapat dibuat oleh seseorang berkisar 0-34 yang diwakili oleh gambar segitiga, untuk abilitas 3-41 buah diwakili gambar segi empat serta kemauan diwakili gambar lingkaran sebanyak 2-37 buah. 
Tabel 4. Tingkat Kreativitas (K), Abilitas (A) dan Willness (W) (Kemauan) Setelah Pelatihan

\begin{tabular}{|c|c|c|c|c|}
\hline No. & Jumlah Siswa & Kreatifitas & Abilitas & $\begin{array}{l}\text { Willingness } \\
\text { (Kemauan) }\end{array}$ \\
\hline & 34 & $38-137$ & $22-96$ & $29-150$ \\
\hline
\end{tabular}

Pada Tabel 4 di atas tingkat kreativitas, abilitas dan kemauan siswa meningkat dengan rentang masing-masing 38-137, 22-96 dan 29-150. Hal ini menunjukkan bahwa pelatihan motivasi berbasis otak mempengaruhi kreativitas, abilitas dan kemauan siswa untuk belajar. Metode Kinesiologi (Rivai, 2006) dan Tes Kreativitas, Abilitas dan Willnes (games motivation) (Soenarno,2006) secara sinergis membuktikan bahwa pelatihan motivasi mampu meningkatkan kemampuan limbic dan kompetensi siswa dalam belajar dari aspek kreativitas, abilitas dan willingness (kemauan).

\section{SIMPULAN}

Pelatihan motivasi berbasis otak terbukti mampu meningkatkan kemampuan limbikdan aspekkreativitas, abilitas dan kemauan siswa SMP dalam belajar.

\section{DAFTAR PUSTAKA}

Rivai ,A. 2006. Kinesiologi Terapan. Yayasan Masag Medan Indian Journal Psychiatry v.49(2); Apr-Jun 2007

Rose, C dan Nicholl, J.M. 2002. Accelerated Learning.(Terjemahan Dedi Ahimsa) Bandung : Penerbit Nuansa

Soenarno, 2006. Game Motivation.Jakarta : Gramedia 